\title{
Intelligent 3D Analysis for Detection and Classification of Breast Cancer
}

\author{
Suzani Mohamad Samuri, Try Viananda Nova Megariani \\ Computing Department, Faculty of Art, Computing and Creative Industry, Universiti Pendidikan Sultan Idris
}

\section{ARTICLE INFORMATION}

Received: June $13^{\text {th }}, 2019$

Revised: November $8^{\text {th }}, 2019$

Available online: November $11^{\text {th }}, 2019$

\section{KEYWORDS}

3D analysis, fuzzy logic, contrast enhancement, feature selection, computer aided diagnosis (CAD)

\section{CORRESPONDENCE}

E-mail: suzani@fskik.upsi.edu.my

\section{INTRODUCTION}

Breast cancer is the leading cause of death for women, accounting for $14 \%$ of cancer mortalities in 2008 [1]. Early detection through X-ray mammography screening has been shown to reduce the mortality rate of this disease [2]. However, $\mathrm{X}$-ray mammography imaging has its limitations, being unable to detect and distinguish with $100 \%$ accuracy the abnormalities in the breast [3]. Other imaging modalities, such as ultrasound and magnetic resonance imaging (MRI), are therefore used in conjunction with X-ray mammography to image the breasts [4]. Most of the breast cancer is detected by the presence of micro calcification [5]. Mammogram readings are usually performed by a radiologist. Variety of factors such as the poor quality of the image, eye fatigue factor, the performance of radiologist could greatly affect the diagnose results [6]. To overcome this problem, several computer aided diagnosis systems (CAD) are developed by researchers in this field for automatic detection of breast cancer [7-10]. This research presents a method for building a classification system or CAD based on 3D analysis, especially to obtain the different characteristics of mass and micro calcification [11-13] using association technique based on classification. The classification process mainly consists of two phases: training phase and testing phase. In the training phase the properties of typical image features are isolated and the training samples are having their object class information. In this study, the statistics features and the Gray Level Co-occurrence Matrix (GLCM) [14-17] based on texture features are extracted. Feature selection is an important step before the process of any classification scheme. In terms of the data used, the importance of data cleaning is considered. The data cleaning is applied in the context of image content mining. 3D analysis of the breast images [19] was used to develop a computational intelligence algorithm for tracking visible cancerous cells between images, as well as for registering breast images taken from different imaging modalities

This study finds the different characteristics of micro calcification and mass [20-22]. The information of centroid and radius provided in Mammographic Image Analysis Society (MIAS) database [23] are used to find and extract the micro calcification and mass. The finding is the candidate regions in mammogram into two categories: micro calcification and mass regions. This finding will help radiologists in their tasks to detect subtle abnormalities in a mammogram. Furthermore, it also helps in making a decision whether a biopsy procedure is necessary or not. A decision of the candidate regions were carefully concluded, especially in selecting the threshold value and size of the candidate regions in order to obtain the candidate regions that highly resemble micro calcification or mass [24-26]. Unfortunately, there are large variations of threshold value from one image to the others, therefore a constant threshold will not be good enough.

The paper is organized as follows; Section I is an introduction and background. Section II provides the detail proposed methodology for micro calcification and mass detection. Section 
III discusses the experiment results. Finally, Section IV presents the concluding remarks.

\section{METHOD}

In this section, the CAD detection scheme involving stage mass is described in Figure 1. Starting with pre-processing image of digital mammograms to reduce noise and improve the contrast of images [27-30], then, the segmentation of the image defined by the majority of articles about the detection of a mass as the location of the suspicious mass. In the third stage, features taken and was chosen to classify the type of lesion or remove false positive. Then, detection and classification of a mass were done. All these work were done using MATLAB 2018b software.

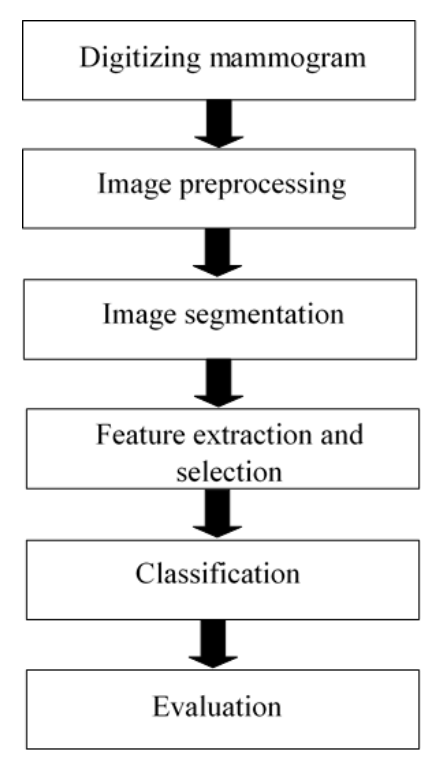

Figure 1. The CAD detection scheme

\section{RESULTS AND DISCUSSION}

\section{Digitizing Mammogram}

At this stage, 100 mammograms data were collected from the Central Pertamina Hospital, Indonesia (50 normal data and 50 cancer) as shown in Figure 2.

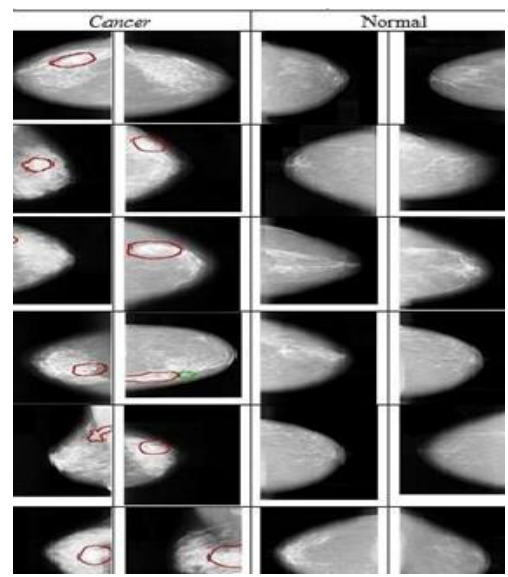

Figure 2. Some of the mammogram of normal and cancer images.

\section{Image Pre-processing}

Several stages involved in image pre-processing to improve image quality as shown in Figure 3, and the results from this preprocessing is shown in Figure 4, where the 3D cancer and normal images can be analyzed and fed to the next process which is the image segmentation.

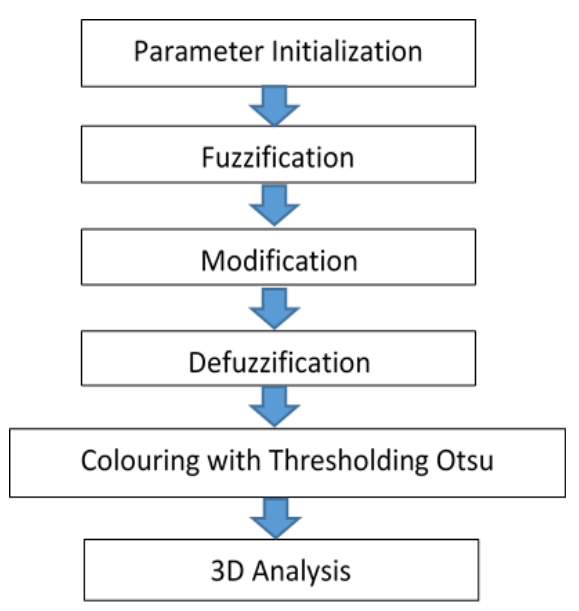

Figure 3. The flowchart of pre-processing stages

In this case, fuzzification involves transforming a crisp quantity into a fuzzy quantity. This can be achieved by identifying the various known crisp and deterministic quantities as completely nondeterministic and quite uncertain in nature. While defuzzification involves converting the fuzzy results into crisp results. This process is capable of generating a non-fuzzy control action which illustrates the possibility distribution of an inferred fuzzy control action. After the process of defuzzification, the thresholding Otsu is used to perform automatic image thresholding [31] by minimizing intra-class intensity variance, or equivalently, by maximizing inter-class variance [32]. The algorithm has been improved to include color scheme to better shown the segments of the breast cancer. 


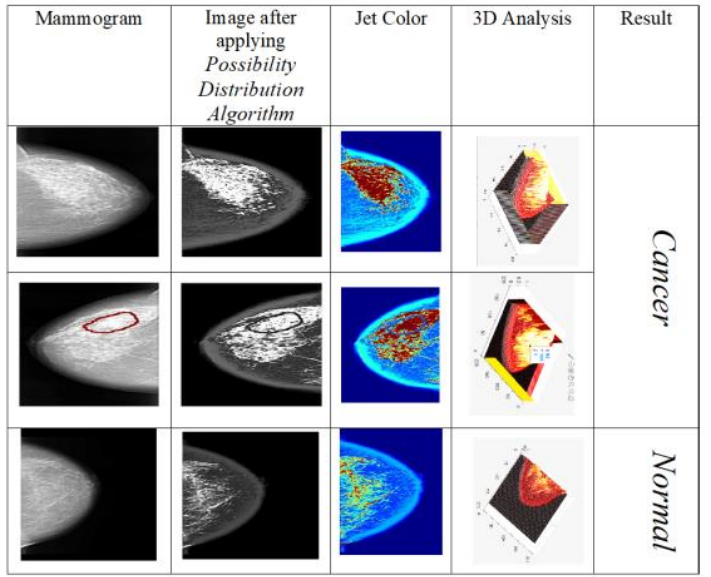

Figure 4. Results from the pre-processing of cancer and normal images

\section{Image Segmentation}

At this stage, Thresholding Otsu algorithm [33-35] is used to segment the pictures by means of distinguished it to the 2 classes , namely background (value set to 0 and object (value set to 1 ) use as a certain level of a parapet. As the result from this segmentation, it can be clearly seen that there are very significant differences between normal and cancer images, in such a way that a mass of data on cancer more than the normal. Figure 5 shows segmentation results from normal image and cancer image.

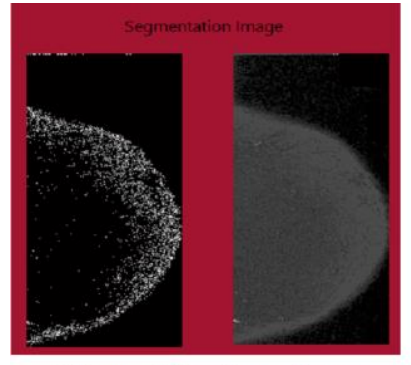

(a) Segmentation of normal image

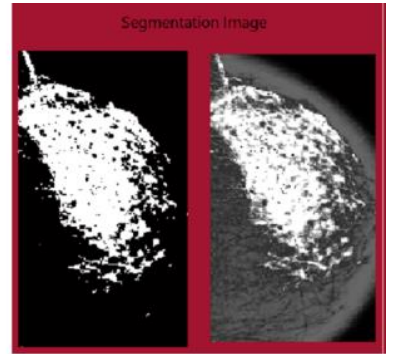

(b) Segmentation of cancer image

\section{Feature Extraction and Selection}

For feature extraction, GLCM (Grey Level Co-occurrence Matrix) is being used. GLCM is the two dimensions represent the level variation gray at the image. GLCM is one of the popular statistical methods of extracting textural feature from images. According to [36], by extracting the features of an image by GLCM approach, the image compression time can be greatly reduced in the process of converting RGB to Gray level image when compared to other discrete wavelet transform (DWT) techniques. In this study, measurement of the correlation, energy, in contrast, entropy, and homogeneity are computed as features extracted and shall be used in the classification stage. Table 1 shows some of the results from GLCM.

\section{Classification}

Neural network is a model that made to imitate the function of learning that owned the human brain.In the neural network, layer neurons were brought in, called neurons layer .Usually each neuron connected to all of a layer of neurons are in the back and front of him except layer input and output. Information sent in a neural network propagation layer started from the input to output through one or more hidden layers. Multilayer Perceptron (MLP) neural network is used in this study to classify the image to be cancer or normal.

\section{Evaluation}

For evaluation, this study used 60 samples, in which 30 of the samples are of cancer images and 30 of them are normal images. As the results from this evaluation, it is found out that only 2 cancer images that could not be classified. This may be due to fat or the images contain spicules. Therefore, the overall performance of the classifier developed is very good with the accuracy of $97 \%$. Table 2 shows some of the example from the evaluation stage.

Figure 5. Segmentation results from normal and cancer images

Table 1. Some of the results from GLCM

\begin{tabular}{ccccccc}
\hline Images & Contrast & Variance & Std Dev & Kurtosis & Mean & Smoothness \\
\hline $\mathbf{1}$ & 1.027975 & 0.395393 & 0.628802 & 9.451290 & 0.539653 & 0.283356 \\
\hline $\mathbf{2}$ & 1.441665 & 0.479333 & 0.692339 & 9.469165 & 0.592580 & 0.324020 \\
\hline $\mathbf{3}$ & 0.745201 & 0.368605 & 0.607128 & 7.047246 & 0.533764 & 0.269329 \\
\hline
\end{tabular}

Table 2. Some of the evaluation results

\begin{tabular}{cccccccccc}
\hline Images & Contrast & Variance & Std Dev & Kurtosis & Mean & Smoothness & Correct & Incorrect \\
\hline $\mathbf{1}$ & 1.027975 & 0.395393 & 0.628802 & 9.451290 & 0.539653 & 0.283356 & $50 \%$ & $50 \%$ \\
\hline $\mathbf{2}$ & 1.441665 & 0.479333 & 0.692339 & 9.469165 & 0.592580 & 0.324020 & $50 \%$ & $50 \%$ \\
\hline $\mathbf{3}$ & 0.745201 & 0.368605 & 0.607128 & 7.047246 & 0.533764 & 0.269329 & $50 \%$ & $50 \%$ \\
\hline
\end{tabular}


Until now, breast cancer is a type of cancer with the largest number of cases in the world, as well as the highest cause of death. In Indonesia, breast cancer occupies the second rank after cervical cancer. Some breast cancers are associated with a typical genetic mutation. Women with this gene mutation have an 80 $90 \%$ chance of developing breast cancer. In breast cancer patients, the impact that can arise is the loss of breast due to breast removal surgery. Apart from that, these cancer cells can also spread to other vital organs such as liver, bones, etc. Study by [37] reported that a significant number of cancers (30-65\%) can be visualized on prior mammograms on retrospective review. Double reading of mammograms by two radiologists can improve the detection rate of cancer but is expensive and time consuming. The goal of Computer Aided Diagnosis (CAD) is to improve detection rates in a more efficient and cost-effective manner, as human examination of images is often influenced by various factors such as fatigue, carelessness, and others. The detection accuracy is also confined by the limitations of the human visual system. In addition to all these factors, a shortage of qualified radiologists also causes an urgent demand for the development of computer technologies. In this case, the developed CAD algorithm with accuracy of $97 \%$ would somehow shed the lights in the field of early breast cancer detection system.

\section{CONCLUSIONS}

Breast cancer can be diagnosed with various screening mechanisms, including mammography, however understanding the mammogram images in the phase of diagnosis is not an easy job. Computer Aided Diagnosis (CAD) are seen as tools that can help radiologist for automatic detection of breast cancer. This research presents a method for building a classification system, especially to obtain the different characteristics of mass and micro calcification using association technique based on classification. The outcome of this research has the potential to help radiologist in diagnosing breast cancer by categorizing breast cancer as benign or malignant. From the results, it is clear that the provision of color map in the final segmentation outcome can give more accurate information especially in differentiating between cancer and non-cancer images. By using threshold masks on segmentation edge, and morphology dilate and the segmentation of borderline and variation of coloring, provide optimal results to distinguish between a class of objects cancer tissue and non-cancer. In the evaluation stage, 60 samples were used. The classifier developed able to perform well by successfully classifying the cancer and non-cancer (normal) images with the accuracy of $97 \%$. Apart from that, by applying color map to the final results of segmentation provides a more interesting display of information and gives more direction to the purpose of image processing, which distinguishes between cancerous and non-cancerous tissues.

This study could also be improved, here are suggestions proposed: 1 .Improving the quality image is a process very decisive in image processing mammograms. The improvement of the image of a method of research needed to gain special a method of improving the quality image of mammograms for better results .2 This research can be extended using other classification method to improve the accuracy. In this study, the classification only focuses on normal and cancer. However, cancer can also be further categorized into benign and malignant background in the division of which there are three categories (fat, the glands of fat, solid) and glands. By giving a direct threshold to the edge segmentation mask, and morphology dilate and borderline segmentation and color variation, it gives optimal results to distinguish between classes of objects between cancerous and noncancerous tissues, and hence can further classify the cancer into stage 1 , stage 2 , stage 3 and stage 4 .

\section{ACKNOWLEDGMENT}

This research study is funded by Universiti Pendidikan Sultan Idris, Malaysia, under the Special University Research Grant (Fundamental), 2017-0184-109-01.

\section{REFERENCES}

[1] Jemal, A., Bray, F., Center, M. M., Ferlay, J., Ward, E., \& Forman, D. (2011). Global cancer statistics. CA: a cancer journal for clinicians, 61(2), 69-90.

[2] Skane, P., Bandos, A. I., Gullien, R., Eben, E. B., Ekseth, U., Haakenaasen, U., \& Niklason, L. T. (2013). Comparison of digital mammography alone and digital mammography plus tomosynthesis in a population-based screening program. Radiology, 267(1), 47-56.

[3] Health Quality Ontario. (2016). Ultrasound as an adjunct to mammography for breast cancer screening: a health technology assessment. Ontario health technology assessment series, 16(15), 1.

[4] Harms, S. E. (2001). Integration of breast MRI in clinical trials. Journal of Magnetic Resonance Imaging: An Official Journal of the International Society for Magnetic Resonance in Medicine, 13(6), 830-836.

[5] Cox, R. F., Hernandez-Santana, A., Ramdass, S., McMahon, G., Harmey, J. H., \& Morgan, M. P. (2012). Microcalcifications in breast cancer: novel insights into the molecular mechanism and functional consequence of mammary mineralisation. British journal of cancer, 106(3), 525.

[6] Krupinski, E. A. (2010). Current perspectives in medical image perception. Attention, Perception, \& Psychophysics, 72(5), 1205-1217.

[7] Castellino, R. A. (2005). Computer aided detection (CAD): an overview. Cancer Imaging, 5(1), 17.

[8] Cole, E. B., Zhang, Z., Marques, H. S., Edward Hendrick, R., Yaffe, M. J., \& Pisano, E. D. (2014). Impact of computer-aided detection systems on radiologist accuracy with digital mammography. American Journal of Roentgenology, 203(4), 909-916.

[9] Jalalian, A., Mashohor, S., Mahmud, R., Karasfi, B., Saripan, M. I. B., \& Ramli, A. R. B. (2017). Foundation and methodologies in computer-aided diagnosis systems for breast cancer detection. EXCLI journal, 16, 113.

[10] The, J. S., Schilling, K. J., Hoffmeister, J. W., Friedmann, E., McGinnis, R., \& Holcomb, R. G. (2009). Detection of breast cancer with full-field digital mammography and computer-aided detection. American journal of roentgenology, 192(2), 337-340.

[11] Mordang, J. J., Gubern-Mérida, A., Bria, A., Tortorella, F., Mann, R. M., Broeders, M. J. M., \& Karssemeijer, N. (2018). The importance of early detection of calcifications associated with breast cancer in screening. Breast cancer research and treatment, 167(2), 451-458.

[12] Razek, N. M. A., Yousef, W. A., \& Mustafa, W. A. (2013). Microcalcification detection with and without CAD system (LIBCAD): A comparative study. The 
Egyptian Journal of Radiology and Nuclear Medicine, 44(2), 397-404.

[13] Stoeblen, F., Landt, S., Ishaq, R., Stelkens-Gebhardt, R., Rezai, M., Skaane, P., \& Kuemmel, S. (2011). Highfrequency breast ultrasound for the detection of microcalcifications and associated masses in BI-RADS 4a patients. Anticancer research, 31(8), 2575-2581.

[14] Biswas, R., Nath, A., \& Roy, S. (2016, September). Mammogram Classification Using Gray-Level Cooccurrence Matrix for Diagnosis of Breast Cancer. In Micro-Electronics and Telecommunication Engineering (ICMETE), 2016 International Conference on (pp. 161-166). IEEE.

[15] Vujasinovic, T., Pribic, J., Kanjer, K., Milosevic, N. T., Tomasevic, Z., Milovanovic, Z., \& Radulovic, M. (2015). Gray-level co-occurrence matrix texture analysis of breast tumor images in prognosis of distant metastasis risk. Microscopy and Microanalysis, 21(3), 646-654.

[16] Pratiwi, M., Harefa, J., \& Nanda, S. (2015). Mammograms classification using gray-level cooccurrence matrix and radial basis function neural network. Procedia Computer Science, 59, 83-91.

[17] Abdelrahman, A., \& Hamid, O. (2012). Breast Ultrasound Images Enhancement Using Gray Level Co-Occurrence Matrices Quantizing Technique. International Journal of Information Science, 2(5), 60-64.

[18] Lee, J., Reece, G. P., \& Markey, M. K. (2012). Breast curvature of the upper and lower breast mound: 3D analysis of patients who underwent breast reconstruction. In 3rd International Conference on 3D Body Scanning Technologies(pp. 171-179).

[19] Li, C. M., Segars, W. P., Tourassi, G. D., Boone, J. M., \& Dobbins, J. T. (2009). Methodology for generating a 3D computerized breast phantom from empirical data. Medical physics, 36(7), 3122-3131.

[20] Nalawade, Y. V. (2009). Evaluation of breast calcifications. Indian Journal of Radiology \& Imaging, 19(4).

[21] Rominger, M. B., Steinmetz, C., Westerman, R., Ramaswamy, A., \& Albert, U. S. (2015). Microcalcification-Associated Breast Cancer: Presentation, Successful First Excision, Long-Term Recurrence and Survival Rate. Breast care, 10(6), 380385.

[22] Naseem, M., Murray, J., Hilton, J. F., Karamchandani, J., Muradali, D., Faragalla, H., ... \& Brezden-Masley, C. (2015). Mammographic microcalcifications and breast cancer tumorigenesis: a radiologic-pathologic analysis. BMC cancer, 15(1), 307.

[23] Suckling, J., Parker, J., Dance, D., Astley, S., Hutt, I., Boggis, C., ... \& Taylor, P. (2015). Mammographic Image Analysis Society (MIAS) database v1. 21.

[24] Herwanto, A. M. A., \& Arymurthy, A. M. (2013). Association technique based on classification for classifying microcalcification and mass in mammogram. IJCSI International Journal of Computer Science Issues, 10(1), 1694-0814.

[25] Gur, D., Abrams, G. S., Chough, D. M., Ganott, M. A., Hakim, C. M., Perrin, R. L., ... \& Bandos, A. I. (2009). Digital breast tomosynthesis: observer performance study. American Journal of Roentgenology, 193(2), 586591.

[26] Bruno, D. O. T., do Nascimento, M. Z., Ramos, R. P., Batista, V. R., Neves, L. A., \& Martins, A. S. (2016). LBP operators on curvelet coefficients as an algorithm to describe texture in breast cancer tissues. Expert Systems with Applications, 55, 329-340.

[27] Bandyopadhyay, S. K. (2010). Pre-processing of Mammogram Images. International Journal of Engineering Science and Technology, 2(11), 6753-6758.

100 Suzani Mohamad Samuri
[28] Bandyopadhyay, S. K. (2010). Detection of abnormal masses in mammogram images. International Journal of Computer Science and Information Technologies, 1(5), 438-442.

[29] Bandyopadhyay, S. K., Maitra, I. K., \& Kim, T. H. (2011, April). Identification of abnormal masses in digital mammography images. In Ubiquitous Computing and Multimedia Applications (UCMA), 2011 International Conference on (pp. 35-41). IEEE.

[30] Ponraj, D. N., Jenifer, M. E., Poongodi, P., \& Manoharan, J. S. (2011). A survey on the preprocessing techniques of mammogram for the detection of breast cancer. Journal of Emerging Trends in Computing and Information Sciences, 2(12), 656-664.

[31] M. Sezgin \& B. Sankur (2004). "Survey over image thresholding techniques and quantitative performance evaluation". Journal of Electronic Imaging. 13 (1): 146165. doi:10.1117/1.1631315.

[32] Liu, Dongju (2009). "Otsu method and K-means". Ninth International Conference on Hybrid Intelligent Systems IEEE. 1: 344-349.

[33] Al-Bayati, M., \& El-Zaart, A. (2013). Mammogram images thresholding for breast cancer detection using different thresholding methods. Advances in Breast Cancer Research, 2(03), 72.

[34] Shanmugavadivu, P., \& Narayanan, S. L. (2013). Segmentation of microcalcifications in mammogram images using intensity-directed region growing. In Computer Communication and Informatics (ICCCI), 2013 International Conference on (pp. 1-6). IEEE.

[35] Swetha, T. L. V. N., \& Bindu, C. H. (2015). Detection of Breast cancer with Hybrid image segmentation and Otsu's thresholding. In Computing and Network Communications (CoCoNet), 2015 International Conference on (pp. 565-570).

[36] Mohanaiah, P., Sathyanarayana, P., \& GuruKumar, L. (2013). Image texture feature extraction using GLCM approach. International journal of scientific and research publications, 3(5), 1.

[37] Elmore, J. G., Armstrong, K., Lehman, C. D., \& Fletcher, S. W. (2005). Screening for breast cancer. Jama, 293(10), 1245-1256. 


\section{APPENDICES}

Table 1. The results from GLCM

\begin{tabular}{|c|c|c|c|c|c|c|}
\hline Pictures & Contrast & Variance & $\begin{array}{c}\text { Std } \\
\text { Deviation }\end{array}$ & Kurtosis & Mean & Smoothness \\
\hline $\begin{array}{l}\text { 1) Input file: } \\
\text {.Data } \\
\text { Training \can } \\
\text { cer001.jpg }\end{array}$ & 1.027.975 & 0.395393 & 0.628802 & 9.451 .290 & 0.539653 & 0.283356 \\
\hline $\begin{array}{l}\text { 2) Input file: } \\
\text {. Data } \\
\text { Training \can } \\
\text { cer002.jpg }\end{array}$ & 1.441 .665 & 0.479333 & 0.692339 & 9.469 .165 & 0.592580 & 0.324020 \\
\hline $\begin{array}{l}\text { 3) Input file: } \\
\text {.Data } \\
\text { Training\can } \\
\text { cer004r.jpg }\end{array}$ & 0.745201 & 0.368605 & 0.607128 & 7.047.246 & 0.533764 & 0.269329 \\
\hline $\begin{array}{l}\text { 4) Input file: } \\
\text {. Data } \\
\text { Training \can } \\
\text { cer005r.jpg }\end{array}$ & 0.656433 & 0.908943 & 0.953385 & 3.050 .584 & 0.969174 & 0.476150 \\
\hline $\begin{array}{l}\text { 5) Input file: } \\
\text {. Data } \\
\text { Training \can } \\
\text { cer007r.jpg }\end{array}$ & 0.533837 & 0.421264 & 0.649048 & 5.056 .693 & 0.494182 & 0.296401 \\
\hline $\begin{array}{l}\text { 6) Input file: } \\
\text {.Data } \\
\text { Training \can } \\
\text { cer008r.jpg }\end{array}$ & 0.831437 & 0.364672 & 0.603880 & 13.703 .958 & 0.437214 & 0.267223 \\
\hline $\begin{array}{l}\text { 7) Input file: } \\
\text {.Data } \\
\text { Training\can } \\
\text { cer009r.jpg }\end{array}$ & 1.786 .484 & 0.756469 & 0.869752 & 4.850 .012 & 0.831375 & 0.430676 \\
\hline $\begin{array}{l}\text { 8) Input file: } \\
\text {. Data } \\
\text { Training\can } \\
\text { cer010r.jpg }\end{array}$ & 0.805781 & 0.254647 & 0.504626 & 22.838 .733 & 0.292154 & 0.202963 \\
\hline $\begin{array}{l}\text { 9) Input file: } \\
\text {.Data } \\
\text { Training \can } \\
\text { cer011r.jpg }\end{array}$ & 2.895 .576 & 0.772208 & 0.878753 & 8.091 .002 & 0.604129 & 0.435732 \\
\hline $\begin{array}{l}\text { 10) Input } \\
\text { file: . (Data } \\
\text { Training\can } \\
\text { cer012r.jpg }\end{array}$ & 1.089.179 & 0.860437 & 0.927597 & 2.971 .478 & 1.005 .752 & 0.462492 \\
\hline $\begin{array}{l}\text { 11) Input } \\
\text { file: . \Data } \\
\text { Training \can } \\
\text { cer013.jpg }\end{array}$ & 1.241 .824 & 0.884123 & 0.940278 & 3.545 .246 & 0.862658 & 0.469249 \\
\hline $\begin{array}{l}\text { 12) Input } \\
\text { file: . \Data } \\
\text { Training } \backslash \text { can } \\
\text { cer014r.jpg }\end{array}$ & 0.480968 & 0.292931 & 0.541231 & 3.243 .053 & 0.522723 & 0.226563 \\
\hline $\begin{array}{l}\text { 13) Input } \\
\text { file: . IData } \\
\text { Training\can } \\
\text { cer015.jpg }\end{array}$ & 0.659686 & 0.384301 & 0.619920 & 7.606 .833 & 0.553142 & 0.277614 \\
\hline $\begin{array}{l}\text { 14) Input } \\
\text { file: . Data } \\
\text { Training \can } \\
\text { cer016.jpg }\end{array}$ & 0.887930 & 0.695458 & 0.833941 & 5.918 .708 & 0.600904 & 0.410189 \\
\hline $\begin{array}{l}\text { 15) Input } \\
\text { file: . (Data } \\
\text { Training\can } \\
\text { cer017.jpg }\end{array}$ & 0.933452 & 0.342092 & 0.584886 & 9.046 .787 & 0.510722 & 0.254895 \\
\hline $\begin{array}{l}\text { 16) Input } \\
\text { file: . IData } \\
\text { Training \can } \\
\text { cer018.jpg }\end{array}$ & 1.046 .170 & 0.268747 & 0.518408 & 13.412 .767 & 0.491343 & 0.211821 \\
\hline $\begin{array}{l}\text { 17) Input } \\
\text { file: . IData } \\
\text { Training\can } \\
\text { cer019.jpg }\end{array}$ & 0.339692 & 0.196974 & 0.443817 & 35.674 .353 & 0.145744 & 0.164560 \\
\hline $\begin{array}{l}\text { 18) Input } \\
\text { file: . IData } \\
\text { Training\can } \\
\text { cer020.jpg }\end{array}$ & 0.979368 & 0.349894 & 0.591519 & 7.787 .264 & 0.545829 & 0.259201 \\
\hline $\begin{array}{l}\text { 19) Input } \\
\text { file: . IData } \\
\text { Training\can } \\
\text { cer021.jpg }\end{array}$ & 0.950996 & 0.545184 & 0.738366 & 6.124.198 & 0.573179 & 0.352828 \\
\hline $\begin{array}{l}\text { 20) Input } \\
\text { file: . IData } \\
\text { Training } \backslash \text { can } \\
\text { cer022.jpg }\end{array}$ & 0.925971 & 1.023 .833 & 1.011 .846 & 2.608.508 & 1.119 .278 & 0.505888 \\
\hline $\begin{array}{l}\text { 21) Input } \\
\text { file: . IData } \\
\text { Training \can } \\
\text { cer023.jpg }\end{array}$ & 1.284 .403 & 0.571494 & 0.755972 & 8.212 .665 & 0.612259 & 0.363663 \\
\hline $\begin{array}{l}\text { 22) Input } \\
\text { file: . (Data } \\
\text { Training\can } \\
\text { cer024.jpg }\end{array}$ & 1.134.268 & 0.373243 & 0.610936 & 13.794.881 & 0.485263 & 0.271797 \\
\hline $\begin{array}{l}\text { 23) Input } \\
\text { file: . (Data } \\
\text { Training\can } \\
\text { cer025.jpg }\end{array}$ & 0.687896 & 0.329313 & 0.573858 & 5.439 .004 & 0.527263 & 0.247732 \\
\hline $\begin{array}{l}\text { 24) Input } \\
\text { file: . IData } \\
\text { Training\can } \\
\text { cer026.jpg }\end{array}$ & 1.180 .353 & 0.689164 & 0.830159 & 5.632 .584 & 0.677333 & 0.407991 \\
\hline
\end{tabular}

\begin{tabular}{|c|c|c|c|c|c|c|}
\hline $\begin{array}{l}\text { 25) Input } \\
\text { file: . (Data } \\
\text { Training\can } \\
\text { cer027.jpg }\end{array}$ & 0.433786 & 0.600241 & 0.774752 & 7.061 .940 & 0.537373 & 0.375094 \\
\hline $\begin{array}{l}\text { 26) Input } \\
\text { file: . .Data } \\
\text { Training\can } \\
\text { cer028.jpg }\end{array}$ & 1.357.183 & 0.323039 & 0.568365 & 10.801 .558 & 0.486268 & 0.244164 \\
\hline $\begin{array}{l}\text { 27) Input } \\
\text { file: . Data } \\
\text { Training\can } \\
\text { cer029.jpg }\end{array}$ & 1.166 .930 & 0.543015 & 0.736895 & 6.540 .144 & 0.635783 & 0.351918 \\
\hline $\begin{array}{l}\text { 28) Input } \\
\text { file: . Data } \\
\text { Training \can } \\
\text { cer030.jpg }\end{array}$ & 1.086 .810 & 0.269325 & 0.518965 & 11.300 .005 & 0.426429 & 0.212180 \\
\hline $\begin{array}{l}\text { 29) Input } \\
\text { file: . \Data } \\
\text { Training \can } \\
\text { cer031.jpg }\end{array}$ & 0.979220 & 0.792064 & 0.889980 & 6.060 .835 & 0.582719 & 0.441984 \\
\hline $\begin{array}{l}\text { 30) Input } \\
\text { file: . (Data } \\
\text { Training\can } \\
\text { cer032.jpg }\end{array}$ & 0.959707 & 0.495989 & 0.704265 & 7.207.502 & 0.597488 & 0.331546 \\
\hline $\begin{array}{l}\text { 31) Input } \\
\text { file: . \Data } \\
\text { Training } \backslash \text { nor } \\
\text { mal001.jpg }\end{array}$ & 0.149032 & 0.022416 & 0.149718 & 26783677 & 0.142766 & 0.021924 \\
\hline $\begin{array}{l}\text { 32) Input } \\
\text { file: . Data } \\
\text { Training } \backslash \text { nor } \\
\text { mal002.jpg }\end{array}$ & 0.396913 & 0.051596 & 0.227149 & 28594185 & 0.238457 & 0.049065 \\
\hline $\begin{array}{l}\text { 33) Input } \\
\text { file: . \Data } \\
\text { Training } \backslash \text { nor } \\
\text { mal003.jpg }\end{array}$ & 0.307292 & 0.030187 & 0.173743 & 6682308 & 0.190521 & 0.029302 \\
\hline $\begin{array}{l}\text { 34) Input } \\
\text { file: . \Data } \\
\text { Training } \backslash \text { nor } \\
\text { mal005r.jpg }\end{array}$ & 0.777644 & 0.201198 & 0.448551 & 15631640 & 0.422361 & 0.167498 \\
\hline $\begin{array}{l}\text { 35) Input } \\
\text { file: . (Data } \\
\text { Training } \backslash \text { nor } \\
\text { mal007r.jpg }\end{array}$ & 1.014.527 & 0.258868 & 0.508790 & 12.827 .915 & 0.420889 & 0.205635 \\
\hline $\begin{array}{l}\text { 36) Input } \\
\text { file: . (Data } \\
\text { Training } \backslash \text { nor } \\
\text { mal008r.jpg }\end{array}$ & 1.073 .570 & 0.306933 & 0.554016 & 8.096 .671 & 0.623820 & 0.234850 \\
\hline $\begin{array}{l}\text { 37) Input } \\
\text { file: . .Data } \\
\text { Training } \backslash \text { nor } \\
\text { mal009r.jpg }\end{array}$ & 0.751702 & 0.156533 & 0.395643 & 20.118 .500 & 0.355901 & 0.135347 \\
\hline $\begin{array}{l}\text { 38) Input } \\
\text { file: . (Data } \\
\text { Training } \backslash \text { nor } \\
\text { mal010r.jpg }\end{array}$ & 0.782944 & 0.110475 & 0.332378 & 28.735 .658 & 0.291524 & 0.099485 \\
\hline $\begin{array}{l}\text { 39) Input } \\
\text { file: . (Data } \\
\text { Training } \backslash \text { nor } \\
\text { mal011r.jpg }\end{array}$ & 0.235302 & 0.061721 & 0.248438 & 89.195 .943 & 0.143664 & 0.058133 \\
\hline $\begin{array}{l}\text { 40) Input } \\
\text { file: . (Data } \\
\text { Training } \backslash \text { nor } \\
\text { mal012r.jpg }\end{array}$ & 0.328074 & 0.046063 & 0.214623 & 98.636 .136 & 0.169926 & 0.044035 \\
\hline $\begin{array}{l}\text { 41) Input } \\
\text { file: . (Data } \\
\text { Training } \backslash \text { nor } \\
\text { mal013r.jpg }\end{array}$ & 0.089443 & 0.016786 & 0.129561 & 2.470 .104 & 0.160746 & 0.016509 \\
\hline $\begin{array}{l}\text { 42) Input } \\
\text { file: . (Data } \\
\text { Training } \backslash \text { nor } \\
\text { mal014r.jpg }\end{array}$ & 0.188233 & 0.020606 & 0.143547 & 3.427.664 & 0.153428 & 0.020190 \\
\hline $\begin{array}{l}\text { 43) Input } \\
\text { file: . \Data } \\
\text { Training } \backslash \text { nor } \\
\text { mal015r.jpg }\end{array}$ & 0.084951 & 0.014619 & 0.120908 & 1.526 .303 & 0.139433 & 0.014408 \\
\hline $\begin{array}{l}\text { 44) Input } \\
\text { file: . \Data } \\
\text { Training } \backslash \text { nor } \\
\text { mal016r.jpg }\end{array}$ & 0.318124 & 0.051689 & 0.227352 & 10.496 .390 & 0.217974 & 0.049148 \\
\hline $\begin{array}{l}\text { 45) Input } \\
\text { file: . (Data } \\
\text { Training } \backslash \text { nor } \\
\text { mal017r.jpg }\end{array}$ & 0.788998 & 0.108960 & 0.330091 & 26.074.141 & 0.303300 & 0.098254 \\
\hline $\begin{array}{l}\text { 46) Input } \\
\text { file: . } . \text { Data } \\
\text { Training } \backslash \text { nor } \\
\text { mal018r.jpg }\end{array}$ & 5.408 .722 & 0.157456 & 0.396807 & 22.624.975 & 0.369341 & 0.136036 \\
\hline $\begin{array}{l}\text { 47) Input } \\
\text { file: . (Data } \\
\text { Training } \backslash \text { nor } \\
\text { mal019r.jpg }\end{array}$ & 0.681340 & 0.071983 & 0.268297 & 10.464 .641 & 0.262203 & 0.067149 \\
\hline $\begin{array}{l}\text { 48) Input } \\
\text { file: . (Data } \\
\text { Training } \backslash \text { nor } \\
\text { mal020r.jpg }\end{array}$ & 0.620242 & 0.073724 & 0.271522 & 6.439 .709 & 0.255898 & 0.068662 \\
\hline $\begin{array}{l}\text { 49) Input } \\
\text { file: . (Data } \\
\text { Training } \backslash \text { nor } \\
\text { mal021.jpg }\end{array}$ & 0.688708 & 0.146310 & 0.382505 & 15.293 .631 & 0.323929 & 0.127635 \\
\hline $\begin{array}{l}\text { 50) Input } \\
\text { file: . .Data }\end{array}$ & 0.257305 & 0.025060 & 0.158304 & 21.863.137 & 0.183297 & 0.024448 \\
\hline
\end{tabular}




\begin{tabular}{|c|c|c|c|c|c|c|}
\hline $\begin{array}{l}\text { Training \nor } \\
\text { mal022.jpg }\end{array}$ & & & & & & \\
\hline $\begin{array}{l}\text { 51) Input } \\
\text { file: . \Data } \\
\text { Training\nor } \\
\text { mal023.jpg }\end{array}$ & 0.096304 & 0.014161 & 0.118998 & 2.025 .034 & 0.097940 & 0.013963 \\
\hline $\begin{array}{l}\text { 52) Input } \\
\text { file: . \Data } \\
\text { Training\nor } \\
\text { mal024.jpg }\end{array}$ & 0.077927 & 0.015871 & 0.125979 & 1.285.351 & 0.147853 & 0.015623 \\
\hline $\begin{array}{l}\text { 53) Input } \\
\text { file: . \Data } \\
\text { Training\nor } \\
\text { mal025.jpg }\end{array}$ & 0.515347 & 0.324569 & 0.569710 & 21.491.535 & 0.307629 & 0.245038 \\
\hline $\begin{array}{l}\text { 54) Input } \\
\text { file: . \Data } \\
\text { Training\nor } \\
\text { mal026.jpg }\end{array}$ & 0.255861 & 0.015645 & 0.125080 & 1.579 .303 & 0.110151 & 0.015404 \\
\hline $\begin{array}{l}\text { 55) Input } \\
\text { file: . \Data } \\
\text { Training\nor } \\
\text { mal027.jpg }\end{array}$ & 0.323657 & 0.035670 & 0.188865 & 43.388 .443 & 0.167092 & 0.034442 \\
\hline $\begin{array}{l}\text { 56) Input } \\
\text { file: . (Data } \\
\text { Training\nor } \\
\text { mal028.jpg }\end{array}$ & 0.148797 & 0.018848 & 0.137288 & 1.819 .557 & 0.181640 & 0.018499 \\
\hline $\begin{array}{l}\text { 57) Input } \\
\text { file: . \Data } \\
\text { Training\nor } \\
\text { mal029.jpg }\end{array}$ & 0.121953 & 0.020460 & 0.143038 & 10.173.960 & 0.159180 & 0.020050 \\
\hline $\begin{array}{l}\text { 58) Input } \\
\text { file: . \Data } \\
\text { Training\nor } \\
\text { mal030.jpg }\end{array}$ & 3.370 .836 & 0.057243 & 0.239255 & 24.555.437 & 0.260783 & 0.054144 \\
\hline $\begin{array}{l}\text { 59) Input } \\
\text { file: . \Data } \\
\text { Training\nor } \\
\text { mal031.jpg }\end{array}$ & 0.620382 & 0.054293 & 0.233008 & 19.159 .720 & 0.263466 & 0.051497 \\
\hline $\begin{array}{l}\text { 60) Input } \\
\text { file: . \Data } \\
\text { Training\nor } \\
\text { mal032.jpg }\end{array}$ & 0.191360 & 0.025589 & 0.159964 & 37.869 .866 & 0.181133 & 0.024950 \\
\hline
\end{tabular}

Table 2. The evaluation results

\begin{tabular}{|c|c|c|c|c|c|c|c|c|}
\hline Picture & Contrast & $\begin{array}{c}\text { Varia } \\
\text { nce }\end{array}$ & Std Dev & $\begin{array}{c}\text { Kurto } \\
\text { sis }\end{array}$ & $\begin{array}{c}\text { Mea } \\
n\end{array}$ & $\begin{array}{c}\text { Smooth } \\
\text { ness }\end{array}$ & $\begin{array}{c}\text { Corre } \\
\text { ct }\end{array}$ & $\begin{array}{c}\text { Incorre } \\
\text { ct }\end{array}$ \\
\hline $\begin{array}{l}\text { 1) Input } \\
\text { file: } \\
\text {. Data } \\
\text { Training } \\
\text { cancer00 } \\
\text { 1.jpg }\end{array}$ & 1.027 .975 & $\begin{array}{l}0.395 \\
393\end{array}$ & $\begin{array}{l}0.6288 \\
02\end{array}$ & $\begin{array}{r}9.451 \\
.290\end{array}$ & $\begin{array}{l}0.539 \\
653\end{array}$ & $\begin{array}{l}0.2833 \\
56\end{array}$ & $\begin{array}{r}50,00 \\
\%\end{array}$ & $50,00 \%$ \\
\hline $\begin{array}{l}\text { 2) Input } \\
\text { file: } \\
\text {.|Data } \\
\text { Training } \\
\text { cancer00 } \\
\text { 2.jpg }\end{array}$ & 1.441 .665 & $\begin{array}{l}0.479 \\
333\end{array}$ & $\begin{array}{l}0.6923 \\
39\end{array}$ & $\begin{array}{r}9.469 \\
.165\end{array}$ & $\begin{array}{l}0.592 \\
580\end{array}$ & $\begin{array}{l}0.3240 \\
20\end{array}$ & $\begin{array}{r}50,00 \\
\%\end{array}$ & $50,00 \%$ \\
\hline \begin{tabular}{l} 
3) Input \\
file: \\
. Data \\
Training \} $\\
{\text { cancer00 }} \\
{\text { 4r.jpg }}$ & 0.745201 & $\begin{array}{l}0.368 \\
605\end{array}$ & $\begin{array}{l}0.6071 \\
28\end{array}$ & $\begin{array}{r}7.047 \\
.246\end{array}$ & $\begin{array}{l}0.533 \\
764\end{array}$ & $\begin{array}{l}0.2693 \\
29\end{array}$ & $\begin{array}{r}50,00 \\
\%\end{array}$ & $50,00 \%$ \\
\hline $\begin{array}{l}\text { 4) Input } \\
\text { file: } \\
\text {.|Data } \\
\text { Training } \backslash \\
\text { cancer00 } \\
\text { 5r.jpg }\end{array}$ & 0.656433 & $\begin{array}{l}0.908 \\
943\end{array}$ & $\begin{array}{l}0.9533 \\
85\end{array}$ & $\begin{array}{r}3.050 \\
.584\end{array}$ & $\begin{array}{l}0.969 \\
174\end{array}$ & $\begin{array}{l}0.4761 \\
50\end{array}$ & $\begin{array}{r}50,00 \\
\%\end{array}$ & $50,00 \%$ \\
\hline $\begin{array}{l}\text { 5) Input } \\
\text { file: } \\
\text {.Data } \\
\text { Training| } \\
\text { cancer00 } \\
\text { 7r.jpg }\end{array}$ & 0.533837 & $\begin{array}{l}0.421 \\
264\end{array}$ & $\begin{array}{l}0.6490 \\
48\end{array}$ & $\begin{array}{r}5.056 \\
.693\end{array}$ & $\begin{array}{l}0.494 \\
182\end{array}$ & $\begin{array}{l}0.2964 \\
01\end{array}$ & $\begin{array}{r}50,00 \\
\%\end{array}$ & $50,00 \%$ \\
\hline $\begin{array}{l}\text { 6) Input } \\
\text { file: } \\
\text {. Data } \\
\text { Training } \\
\text { cancer00 } \\
\text { 8r.jpg }\end{array}$ & 0.831437 & $\begin{array}{l}0.364 \\
672\end{array}$ & $\begin{array}{l}0.6038 \\
80\end{array}$ & $\begin{array}{l}13.70 \\
3.958\end{array}$ & $\begin{array}{l}0.437 \\
214\end{array}$ & $\begin{array}{l}0.2672 \\
23\end{array}$ & $\begin{array}{r}50,00 \\
\%\end{array}$ & $50,00 \%$ \\
\hline $\begin{array}{l}\text { 7) Input } \\
\text { file: } \\
\text {. Data } \\
\text { Training } \\
\text { cancer00 } \\
\text { 9r.jpg }\end{array}$ & 1.786 .484 & $\begin{array}{l}0.756 \\
469\end{array}$ & $\begin{array}{l}0.8697 \\
52\end{array}$ & $\begin{array}{r}4.850 \\
.012\end{array}$ & $\begin{array}{l}0.831 \\
375\end{array}$ & $\begin{array}{l}0.4306 \\
76\end{array}$ & $\begin{array}{r}50,00 \\
\%\end{array}$ & $50,00 \%$ \\
\hline $\begin{array}{l}\text { 8) Input } \\
\text { file: } \\
\text {.Data } \\
\text { Training } \backslash \\
\text { cancer01 } \\
\text { Or.jpg }\end{array}$ & 0.805781 & $\begin{array}{l}0.254 \\
647\end{array}$ & $\begin{array}{l}0.5046 \\
26\end{array}$ & $\begin{array}{l}22.83 \\
8.733\end{array}$ & $\begin{array}{l}0.292 \\
154\end{array}$ & $\begin{array}{l}0.2029 \\
63\end{array}$ & $\begin{array}{r}50,00 \\
\%\end{array}$ & $50,00 \%$ \\
\hline \begin{tabular}{l} 
9) Input \\
file: \\
. Data \\
Training \} $\\
{\text { cancer01 }} \\
{\text { 1r.jpg }}$ & 2.895 .576 & $\begin{array}{l}0.772 \\
208\end{array}$ & $\begin{array}{l}0.8787 \\
53\end{array}$ & $\begin{array}{r}8.091 \\
.002\end{array}$ & $\begin{array}{l}0.604 \\
129\end{array}$ & $\begin{array}{l}0.4357 \\
32\end{array}$ & $\begin{array}{r}50,00 \\
\%\end{array}$ & $50,00 \%$ \\
\hline
\end{tabular}
\end{tabular}
\end{tabular}

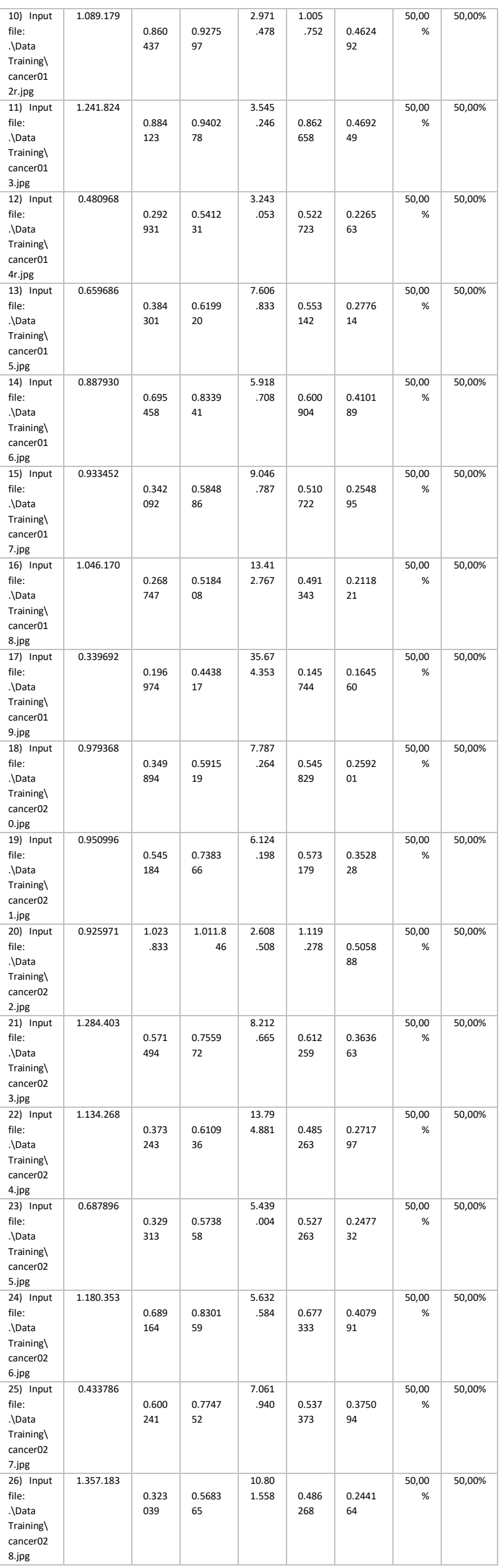

https://doi.org/10.25077/jitce.3.02.96-103.2019 


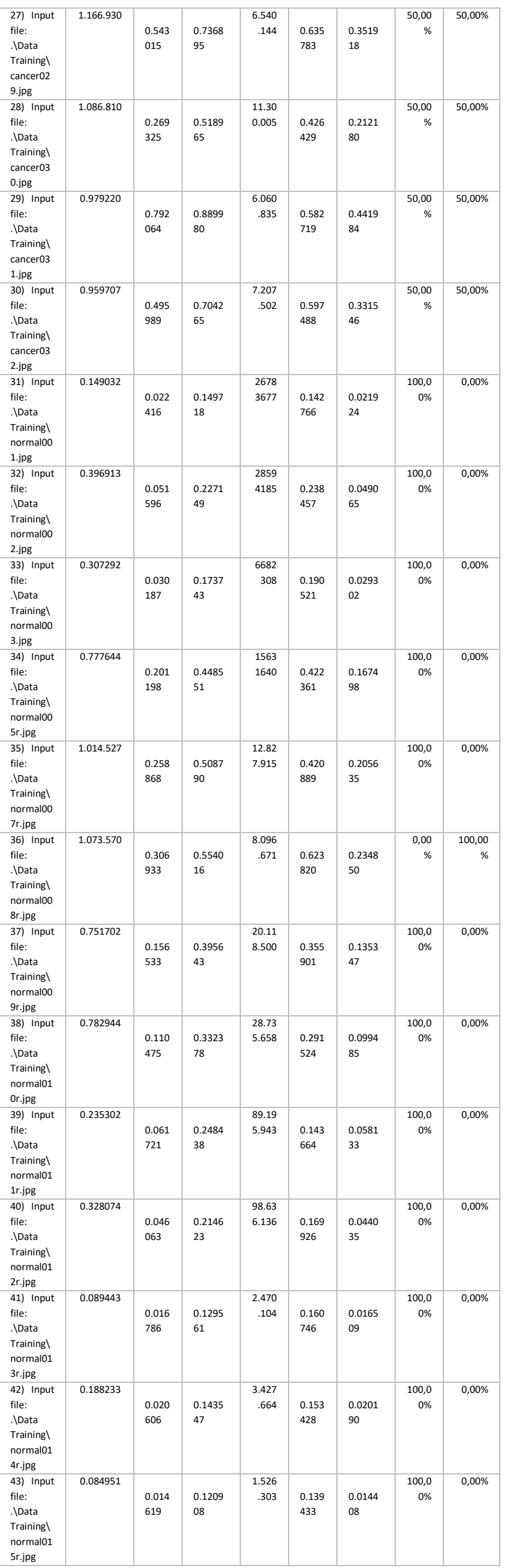

https://doi.org/10.25077/jitce.3.02.96-103.2019

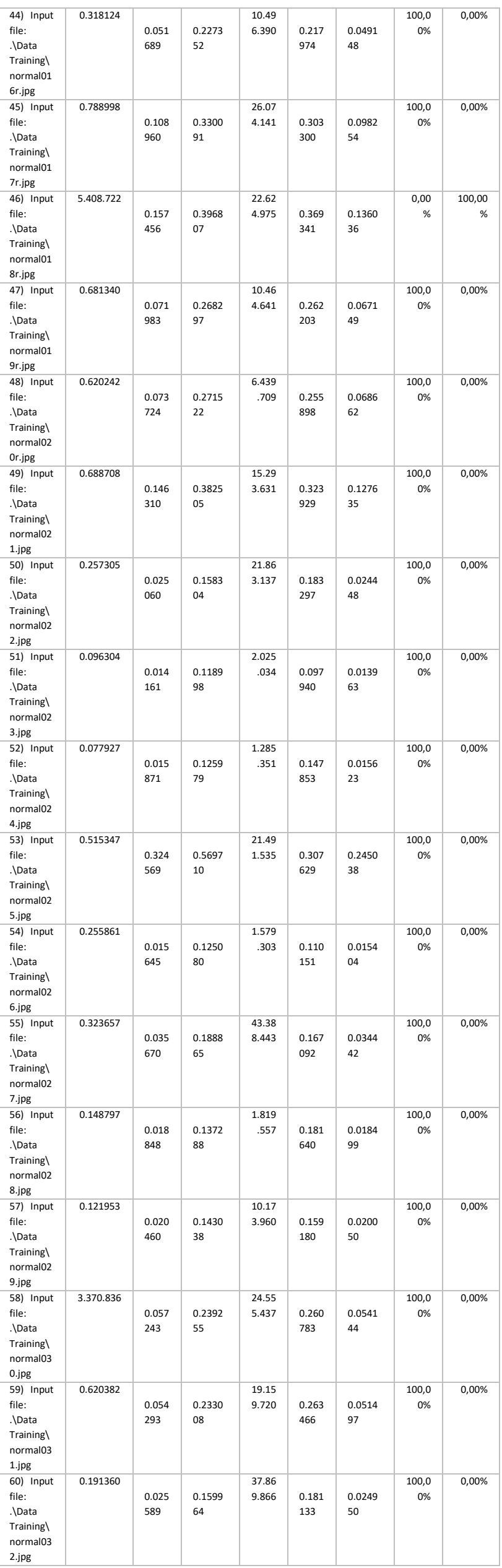

Suzani Mohamad Samuri 